\title{
遺伝子発現量データを用いた AOPに基づく肝毒性評価の可能性
}

\author{
赤堀有美, ${ }^{*}$ 山下京介, 石田和也, 齋藤文代, ${ }^{\dagger}$ 中井 誠
}

\section{Transcriptomics-driven Evaluation on Liver Toxicity Using Adverse Outcome Pathways(AOP)}

\author{
Yumi Akahori, ${ }^{*}$ Kyousuke Yamashita, Kazuya Ishida, Fumiyo Saito, ${ }^{\dagger}$ and Makoto Nakai \\ Chemicals Assessment and Research Center, Chemicals Evaluation and Research \\ Institute (CERI); 1-4-25 Kouraku, Bunkyo-ku, Tokyo 112-0004, Japan.
}

(Received August 1, 2019)

\begin{abstract}
Because the liver is the primary target organ for chemicals and pharmaceuticals, evaluation of these substances' liver toxicity is of critical importance. New evaluation methods without animal testing (i.e., in vitro and/or in silico) are eagerly anticipated, both for animal welfare and for decreasing cost. Also, the importance of mechanistic interpretation of the output derived from non-animal testing has been increasing. Accordingly, we investigated the potential for evaluating liver toxicity by applying the adverse outcome pathway (AOP) concept using gene set enrichment analysis (GSEA) from gene expression (GEx) data. A case study targeting hepatocellular fatty degeneration (HFD) is reported and discussed. We first identified the events detectable in an in vitro system by comparing the GEx data from the rat primary hepatocyte (in vitro) and rat liver (in vivo) treated with a chemical with the ability to induce HFD as one of the phenotypes in a 28-day repeated-dose toxicity test. Then, the scores based on GSEA were calculated after establishing the gene sets for each event leading to HFD. As a result, the mechanistic information leading to HFD was obtained from the score calculated based on the GSEA and the usefulness of the transcriptome-driven evaluation using AOP was demonstrated.
\end{abstract}

Key words - liver toxicity; gene set enrichment analysis; adverse outcome pathway

\section{1. はじめに}

肝臓は，代謝や解毒，胆汁の生成・分泌等を担う 主要な臟器であり, 肝臓における薬物代謝で生成す る活性代謝物の影響等により毒性の標的となる可能 性の高い臓器である。実際に, 肝臓への影響は, 医 薬品だけでなく，一般化学物質の 28 日間反復投与 毒性試験においても最も高頻度で認められる毒性影

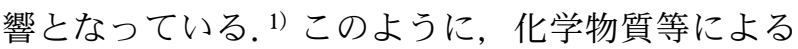
肝臓への影響評価は非常に重要である。近年は動物 愛護の観点，試験期間や費用の削減等のニーズの高 まりから, in vitro 試験や in silicoにより肝毒性を 評価することが望まれている，しかし，実験動物を 使用しない評価を行う場合，毒性が引き起こされる 可能性について, in vitro 試験や in silicoにより提

一般財団法人化学物質評価研究機構安全性評価技術研 究所 ( $=112-0004$ 東京都文京区後楽 1-4-25)

現所属: †岡山理科大学獣医学部獣医学科（下794-8555 愛媛県今治市いこいの丘 $1-3$ )

*e-mail: akahori-yumi@ceri.jp

本総説は, 日本薬学会第 139 年会シンポジウム S52 で 発表した内容を中心に記述したものである.
供される情報と毒性の表現型，すなわち有害性発現 (adverse outcome; AO) との生物学的関係性につ いての説明が必要になる。近年, この説明のための 概念の 1 つとして，2010 年に米国の Ankley ら²)が 提案した，毒性（有害影響）に至る生物学的な応答 経路を整理する有害性発現経路（adverse outcome pathway; AOP) がある. AOP は米国や欧州, 経済 協力開発機構 (Organisation for Economic Co-operation and Development; OECD) 等において受け入 れられており, ${ }^{3,4)}$ OECD は米国や欧州の協力を得 ながら，2012 年から OECD プログラムの一環とし て AOP 開発を行っている。ここで, 遺伝子発現量 (gene expression; GEx) データを扱うトランスクリ プトーム解析は, 一度に数万種類の mRNA の発現 量測定が可能であり, 網羅的に生物学的な応答が得 られるため，AOP のフレームワークにおける活用 も検討されている.5) しかし，AOP を構成する主要 イベント（key event；KE）に関連する遺伝子（群） やパスウェイを定量的に評価する方法の開発が課題

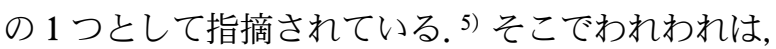


Table 1. Summary of Molecular Initiating Events (MIEs) and Key Events (KEs) from Existing AOPs for Steatosis/Fatty Liver

\begin{tabular}{|c|c|c|c|c|}
\hline MIEs/KE & Items & $\begin{array}{c}\text { Liver Steatosis AOP } \\
(\text { Homo sapiens }) \\
\text { [WikiPathway }]^{6)}\end{array}$ & $\begin{array}{c}\text { Knapen et al., } \\
2018^{7)}\end{array}$ & $\begin{array}{l}\text { AOPwiki/JRC } \\
\text { report, 2012 }\end{array}$ \\
\hline \multirow{12}{*}{ MIEs } & PPAR alpha & $\sqrt{ }$ & $\sqrt{ }$ & antagonism \\
\hline & PPAR delta & $\sqrt{ }$ & & \\
\hline & PPAR gamma & $\sqrt{ }$ & $\sqrt{ }$ & activation \\
\hline & AhR & activation & & agonism \\
\hline & LXR & activation & $\sqrt{ }$ & activation \\
\hline & CAR & activation & \multirow{4}{*}{ Cross-talk } & \\
\hline & PXR & activation & & activation \\
\hline & FXR & & & \\
\hline & RXR & & & \\
\hline & ER & & & $\sqrt{ }$ \\
\hline & $\beta$-adrenergic receptor & & $\sqrt{ }$ & \\
\hline & $\mathrm{PI} 3 \mathrm{~K} / \mathrm{AKT}$ & & $\checkmark$ & \\
\hline \multirow{6}{*}{$\mathrm{KE}$} & Increase of fatty acid intake & & $\sqrt{ }$ & \\
\hline & Increase of de novo fatty acid synthesis & $\sqrt{ }$ & $\sqrt{ }$ & $\sqrt{ }$ \\
\hline & Inhibition of fatty acid oxidation & $\checkmark$ & $\sqrt{ }$ & $\sqrt{ }$ \\
\hline & $\begin{array}{l}\text { Fatty acid or lipid influx } \\
\text { Activate lipogenesis }\end{array}$ & Fatty acid & Lipid & Fatty acid \\
\hline & Fatty acid accumulation & & $\sqrt{ }$ & \\
\hline & Triglyceride accumulation & $\sqrt{ }$ & $\sqrt{ }$ & $\sqrt{ }$ \\
\hline
\end{tabular}

PI3K: phosphatidylinositol-3-kinase; AKT: protein kinase B; PPAR: peroxisome proliferator-activated receptor; LXR: liver X receptor; CAR: constitutive androstane receptor; PXR: pregnane X receptor; FXR: farnesoid X receptor; RXR: retinoid X receptor; AhR: aryl hydrocarbon receptor; ER: estrogen receptor.

GEx で評価可能と考えられる肝毒性に係る KE を 特定し，その KE に適用可能な遺伝子セットを作成 した上で, gene set enrichment analysis（GSEA）を 用いた KE の定量化を行い, 肝毒性評価の可能性に ついて検討した．また，実験動物を必要としない肝 毒性評価系とするために，GSEA を行う際には ラット初代培養肝細胞（rat primary hepatocyte; $\mathrm{rPH}$ ）を用いた in vitro 試験由来の GEx を用いて 検討を行った。本報告では，ケーススタディーとし て, 肝毒性のうち, 脂肪性肝炎や肝硬変など重篤な 肝機能障害につながる可能性がある肝細胞脂肪変性 の解析例を紹介する.

\section{2. 既存情報の収集}

本検討を実施するにあたつては，まず WikiPathways ${ }^{6)}$ や文献情報に基づき，肝細胞脂肪 変性を 1 つの表現型に持つ脂肪肝（hepatic steatosis）に関する既存の AOP を収集した (Table 1). ${ }^{7,8)}$
収集した AOP において複数の報告があつた分子開 始イベント (molecular initiating event; MIE)には, aryl hydrocarbon receptor (AhR), constitutive androstane receptor (CAR), liver $\mathrm{X}$ receptor (LXR), pregnane $\mathrm{X}$ receptor (PXR), peroxisome proliferator-activation receptor $\alpha(\operatorname{PPAR} \alpha)$ 及び $\operatorname{PPAR} \gamma$ があった. また, KE には, 脂肪酸取り込みの増加, de novo 脂肪酸合成の充進, 脂肪酸の酸化抑制, 脂 質輸送の阻害及びトリグリセリドの蓄積があった。

\section{3. 物質間で共通性のあるイベントの特定}

$\mathrm{AOP}$ に包含される KE は個別物質特有のメカ二 ズムではなく，他の物質の評価に利用できるように するため，複数の物質において共通である必要があ る。そこで, 個別物質のラットの肝臓における in vivo の GEx デー夕を解析することで，GEx デー夕 から評価可能であり，物質間で共通した KE を探索 した。 
Table 2. Summarized Protocols and Microarray Platform Used in Tox-Omics and Toxicogenomics Projects

\begin{tabular}{|c|c|c|}
\hline Items & Tox-Omics Project & Toxicogenomics Project (TGP) \\
\hline Experimental animals & $\begin{array}{l}\text { Crl:CD (SD) rat (male) } \\
5 \text { week-old }\end{array}$ & $\begin{array}{l}\mathrm{Crl}: \mathrm{CD}(\mathrm{SD}) \text { rat (male) } \\
6 \text { week-old }\end{array}$ \\
\hline Duration & $\begin{array}{l}\text { Single dose }(1 \mathrm{~d}) \\
7 \mathrm{~d}, 14 \mathrm{~d} \text { and } 28 \mathrm{~d} \text { repeated dose }\end{array}$ & $\begin{array}{l}\text { Single dose }(1 \mathrm{~d}) \\
3 \mathrm{~d}, 7 \mathrm{~d}, 14 \mathrm{~d} \text { and } 28 \mathrm{~d} \text { repeated dose }\end{array}$ \\
\hline Route of administration & Gavage & Gavage \\
\hline Treatment groups & $\begin{array}{l}\text { Vehicle control, Low, High Dose. } \\
4 \text { animals/group for } 1 \mathrm{~d}, 7 \mathrm{~d} \text { and } 14 \mathrm{~d} \text {. } \\
5 \text { animals/group for } 28 \mathrm{~d} \text {. }\end{array}$ & $\begin{array}{l}\text { Vehicle control, Low, Middle, High Dose. } \\
5 \text { animals/group. }\end{array}$ \\
\hline Dose setting & $\begin{array}{l}\text { Maximum tolerated dose was set at the high dose } \\
\text { after a } 7 \text {-day preliminary test. } 1 / 5 \text { th of that dose } \\
\text { was set as the low dose, in principle. }\end{array}$ & $\begin{array}{l}\text { Maximum tolerated dose was set at the high dose } \\
\text { after a } 7 \text {-day preliminary test. The low, middle and } \\
\text { high dose levels were set at the ratios of } 1: 3: 10 \text {, } \\
\text { in principle. }\end{array}$ \\
\hline Anesthesia & $\mathrm{CO}_{2} / \mathrm{O}_{2}$ gas anesthesia $\left(\mathrm{CO}_{2}: \mathrm{O}_{2}=4: 1\right)$ & Ether anesthesia \\
\hline Observation items & $\begin{array}{l}\text { - Clinical observations } \\
\text { - Functional observations } \\
\text { - Body weight } \\
\text { - Food consumption } \\
\text { - Urinalysis } \\
\text { - Hematology } \\
\text { - Blood chemistry } \\
\text { - Organ weights } \\
\text { - Macroscopic observation } \\
\text { - Histopathology }\end{array}$ & $\begin{array}{l}\text { - Clinical observations } \\
\text { - Body weight } \\
\text { - Food consumption } \\
\text { - Urinalysis (occasionally) } \\
\text { - Hematology } \\
\text { - Blood chemistry } \\
\text { - Organ weights (Liver and kidney) } \\
\text { - Macroscopic observation (Liver and kidney) } \\
\text { - Histopathology (Liver and kidney) }\end{array}$ \\
\hline Sampling point & $\begin{array}{l}\text { Single dose: } 24 \mathrm{~h} \text { after treatment } \\
\text { Repeated dose: } 24 \mathrm{~h} \text { after final treatment }\end{array}$ & $\begin{array}{l}\text { Single dose: } 3,9 \text { and } 24 \mathrm{~h} \text { after treatment } \\
\text { Repeated dose: } 24 \mathrm{~h} \text { after final treatment }\end{array}$ \\
\hline Sampling organs & Liver, kidney & Liver, kidney \\
\hline Microarray platform & $\begin{array}{l}\text { Whole Rat Genome Microarray } 8 \times 60 \mathrm{~K} \text { Toxplus } \\
\text { ver. } 2 \text { (Agilent) }\end{array}$ & Rat Genome 2302.0 Array (Affymetrix) \\
\hline Note & $\begin{array}{l}\text { Microarray experiment; } \\
\text { Three samples/group for } 28 \mathrm{~d} \text { were analyzed by } \\
\text { microarray experiment. } \\
\text { Three samples/group for } 1 \mathrm{~d}, 7 \mathrm{~d} \text { and } 14 \mathrm{~d} \text { were } \\
\text { pooled for the microarray experiment. }\end{array}$ & $\begin{array}{l}\text { Three samples/group for } 1 \mathrm{~d}, 3 \mathrm{~d}, 7 \mathrm{~d}, 14 \mathrm{~d} \text { and } \\
28 \mathrm{~d} \text { were analyzed by microarray experiment, in } \\
\text { principle. }\end{array}$ \\
\hline
\end{tabular}

3-1. GEx 解析に使用したデー夕 In vivo GEx データとして, 2011 年から 5 力年で実施され た経済産業省における「研究開発項目(1)遺伝子発現 変動データから各種毒性の発現可能性を取得する手 法の開発」事業 (Tox-Omics プロジェクト) ${ }^{9)}$ 及び 独立行政法人医薬基盤研究所, 国立医薬品食品衛生 研究所及び製薬企業が参画したトキシコゲノミクス プロジェクト (Toxicogenomics Project; TGP) ${ }^{10)} に$ おいて取得されたラットを用いた動物試験デー夕及 び肝蔵における GEx データを使用した。各プロ ジェクトの動物試験条件, マイクロアレイプラット
フォーム等を Table 2 に示す.

3-2. GEx 解析に基づく物質共通性のある KE の 探索解析に供した物質は, Tox-Omics 及び TGP で実施された 28 日までの反復投与毒性試験で 肝細胞脂肪変性が認められた carbon tetrachloride $\left(\mathrm{CCl}_{4}\right)$, bromodichloromethane (BDCM), tetracycline (TC), coumarin (CMA) 及び ethinyl estradiol（EE）とした（Table 3)。さらに，TGP の 28 日までの反復投与毒性試験では肝細胞への脂肪 蓄積は認められていないが, 肝細胞への脂肪蓄積が 既知の Ethionine ${ }^{11)}$ を加えた 6 物質の肝臓における 
Table 3. Summary of the Histopathological Findings of the Liver

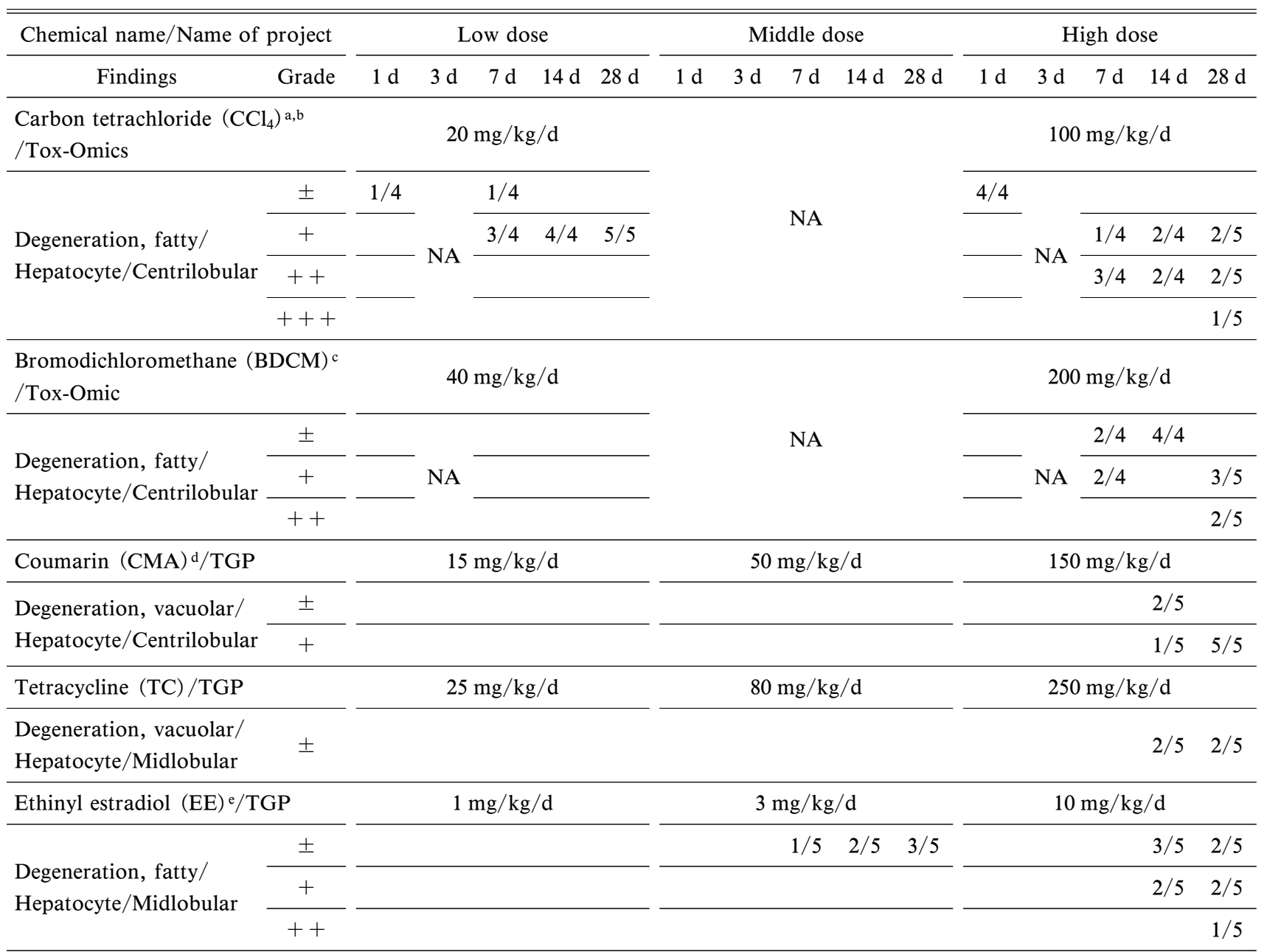

NA: Not applicable. a Necrosis/Hepatocyte/Focal was observed in one animal from the vehicle control group (1-day treatment). ${ }^{\mathrm{b}}$ Other findings in the $\mathrm{CCl}_{4}$ treatment group: Degeneration, hydropic/Hepatocyte/Centrilobular; Mitosis increased; Single cell necrosis/Hepatocyte/Centrilobular; Necrosis/Hepatocyte/ Focal; Microgranuloma. ${ }^{c}$ Other findings in the BDCM group: Hypertrophy/Hepatocyte/Periportal; Hypertrophy/Hepatocyte/Centrilobular; Necrosis, single cell/Hepatocyte; Necrosis/Hepatocyte/Multifocal; Necrosis/Hepatocyte/Focal; Microgranuloma. ${ }^{\mathrm{d}}$ Other findings in the CMA treatment group: Hypertrophy/ Hepatocyte/Centrilobular; Change, eosinophilic/Hepatocyte/Centrilobular; Necrosis, single cell/Hepatocyte/Centrilobular, Inclusion body/Hepatocyte/ Diffuse. ${ }^{e}$ Other findings in the EE treatment group: Hypertrophy/Hepatocyte/Centrilobular; Change, eosinophilic/Hepatocyte/Periportal; Single cell, necrosis/ Hepatocyte; Proliferation/Kupffer cell/Diffuse; Dilatation/Sinusoid/Diffuse.

GEx データについて, Ingenuity ${ }^{\circledR}$ Pathways Analysis $\left(\mathrm{IPA}^{\circledR}\right)$ ソフトウェアによるパスウェイ解析及 び機能解析を実施した。 その結果, GEx 解析によ る物質共通性のある KE としてコレステロール生合 成の克進，ステロイド代謝充進，アミノ酸代謝六進 及び炎症応答があった（Table 4)。また，八ロゲン 化アルキルの $\mathrm{CCl}_{4}$ 及び $\mathrm{BDCM}$ においては，脂肪 蓄積からさらに重篤な脂肪性肝炎や線維化の一因と なる炎症応答12)も確認できた.

なお, 本検討では肝細胞における空胞変性（Degeneration, vacuolar）及び脂肪変性（Degeneration, fatty）はいずれも肝細胞への脂肪蓄積として 扱つた. 13)

\section{4. ラット初代培養肝細胞（rPH）の GEx を用 いた GSEA}

4-1. GSEA について GSEA は，個々の遺伝 子ではなく，あらかじめ定義した遺伝子セット（例 えば，AhRパスウェイに関連する遺伝子セットや 炎症応答という機能に関連する遺伝子セット等）と 実験で得られた遺伝子の間に統計学的に有意な差異 があるかを検定することで，実験で得られた遺伝子 の変化における生物学的意味等を解釈する方法であ る. ${ }^{14,15)}$ GSEA を行うためには，解析したい機能等 に関する遺伝子セットが必要となるが，遺伝子セッ トを大規模に収載している Molecular Signature Database（MSigDB）16）に，捉えたい現象を示す 
Table 4. Summary of the Identified Key Events from Rat Liver Transcriptomics

\begin{tabular}{|c|c|c|c|c|c|c|c|}
\hline \multirow[b]{2}{*}{ Chemical Name/Project Name } & \multicolumn{7}{|c|}{ Identified Key Events } \\
\hline & 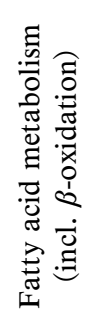 & 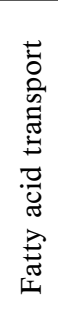 & 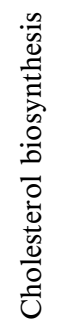 & 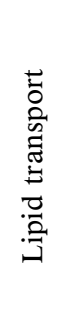 & 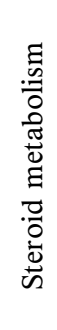 & 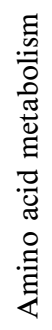 & 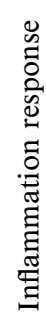 \\
\hline Carbon tetrachloride $\left(\mathrm{CCl}_{4}\right) /$ Tox-Omics & $\nabla$ & $\nabla$ & $\triangle$ & $\nabla$ & & $\boldsymbol{\nabla}$ & $\triangle$ \\
\hline Bromodichloromethane (BDCM)/Tox-Omics & $\nabla$ & $\nabla$ & & $\nabla$ & $\nabla$ & $\nabla$ & $\triangle$ \\
\hline D,L-Ethionine $(\mathrm{ET}) / \mathrm{TGP}$ & $\nabla$ & $\nabla$ & $\triangle$ & $\nabla$ & $\nabla$ & $\boldsymbol{\nabla}$ & \\
\hline Coumarin (CMA)/TGP & $\boldsymbol{\nabla}$ & & & $\nabla$ & $\nabla$ & $\boldsymbol{\nabla}$ & \\
\hline Tetracycline (TC)/TGP & & $\nabla$ & $\triangle$ & & & & \\
\hline Ethinyl estradiol (EE)/TGP & $\boldsymbol{\nabla}$ & $\nabla$ & & $\nabla$ & $\nabla$ & $\boldsymbol{\nabla}$ & \\
\hline
\end{tabular}

$\triangle$ : activated, $\mathbf{\nabla}$ : repressed/inhibited.

遺伝子セットがない，あるいは個々の遺伝子セット が大き過ぎる等により，肝細胞脂肪変性に至る $\mathrm{KE}$ として適切な遺伝子セットがなく，新たに遺伝子 セットを作成する必要が生じた。

4-2. GSEA のための遺伝子セットの作成 AOP に含まれる KE は, in silico 又は in vitro 試 験で評価できることが望ましく，また，in vitro 試 験を実施する場合には，コストの観点からはその数 が少ないことが望ましい，そこで，Table 4 に示し た in vivo（ラットの肝臓）の GEx から特定できた $\mathrm{KE}$ のうち，直接的な肝細胞における脂肪蓄積及び 重篤化に関与している Fatty acid metabolism, Fatty acid/Lipid transport, Cholesterol biosynthesis, Inflammation response に加え, Table 1 において 3 つの既存 AOP に共通しており，GEx で捉えられる 可能性があると考えられた de novo fatty acid synthesis の 5 つの KE について, GSEA のための遺伝 子セットを以下の手順で作成した。 なお，rPH に おける GEx は TGP においての夕取得されている ことから，遺伝子セットは TGP のデータを用いて 作成した.

1） TGP でラット肝臓及び rPH における GEx データがある物質から 28 日間の反復投与で肝細 胞脂肪変性が認められた物質あるいは脂肪肝を引 き起こすことが知られている物質を選定した（6 物質; ET, CMA, EE, Ethionamide, Clomipra- mine, 2-Bromoethylamine).

2）選定した物質の最高用量における in vivo 及 び in vitro 試験の GEx データから変動遺伝子を 抽出し，各系で共通して変動する遺伝子リストを 作成した.

3）遺伝子セットを作成する KE 毎に，論文情報

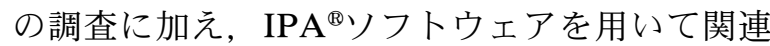
遺伝子群を抽出した。

4） 2）で作成した遺伝子リストと及び 3）で抽 出した関連遺伝子群を照合し, 発現変動の大きさ を考慮しつつ, 被験物質の暴露により生じた応答 と関連性の高い遺伝子に絞り込んだ.

5）肝毒性の報告がない 4 物質 (Glibenclamide, Moxisylyte, Famotidine, Triazolam) において in vivo 及び in vitro 試験で共通で変動した遺伝子 リスト（陰性物質遺伝子リスト）を作成し，陰性 2 物質以上で変動した遺伝子については，4）で 作成したリストから除外して，最終的な遺伝子 セットとした。

作成した遺伝子セットに含まれる遺伝子数を Table 5 に示す.

4-3. ラット初代培養肝細胞（rPH）の GEx を用 いた GSEA Broad Institute から提供されている GSEA のプログラム17) を用いて, normalized enrichment score（NES）及び，遺伝子セットに含ま れる遺伝子数に対して該当した遺伝子数の割合を示 
Table 5. Gene Set Names and Number of Genes in Each Gene Set

\begin{tabular}{lc}
\hline \hline \multicolumn{1}{c}{ Gene set name } & No. of genes in each gene set \\
\hline Inhibition of FA metabolism & 121 \\
\hline Inhibition of Lipid Transport & 36 \\
\hline Cholesterol Biosynthesis & 36 \\
\hline de novo FA Synthesis & 56 \\
\hline Inflammatory Response & 19 \\
\hline
\end{tabular}

FA: Fatty acid.

す Hit Ratio を算出した，遺伝子セット作成に用い た物質の結果を Fig. 1 に示す. NES では当該遺伝 子セットに含まれる遺伝子群が全体として up-regulate 又は down-regulate されたかを正負の符号で表 現されている．例えば，Fig. 1 に示す脂肪酸代謝の 遺伝子セットはいずれの物質においても負の值を示 しており，脂肪酸代謝が抑制されている可能性があ ることが示唆され，in vivo 系で検出された応答を
反映した結果が得られた。ここで，EEについては， 28 日間投与したラットの肝臓において肝細胞脂肪 変性が認められているが，rPHの GEx を用いた GSEA の Hit Ratio が小さかったことから，今回使 用した EE の in vitro 系の GEx データでは KE の応 答が十分に捉えられていないことが分かった。 その ため，エストロゲン受容体が介在すると考えられる 肝細胞への脂肪蓄積については，今回選定した遺伝 子セットでは評価できない可能性が考えられた。一 方，陰性物質の 4 物質については， NES 及び Hit Ratio が算出されない又は, Hit Ratio が低く変動 した遺伝子の数が少ない傾向があった。このことか ら，変動遺伝子数を指標とした Hit Ratio の值から KE の影響の強さが推定できる可能性があると考え られた.

さらに，遺伝子セット作成に使用していない，肝 細胞脂肪変性の病理組織学的所見が認められた 9 物 質 [Adapin, Amitriptyline, Azathioprine, $\mathrm{CCl}_{4}$, Dil-

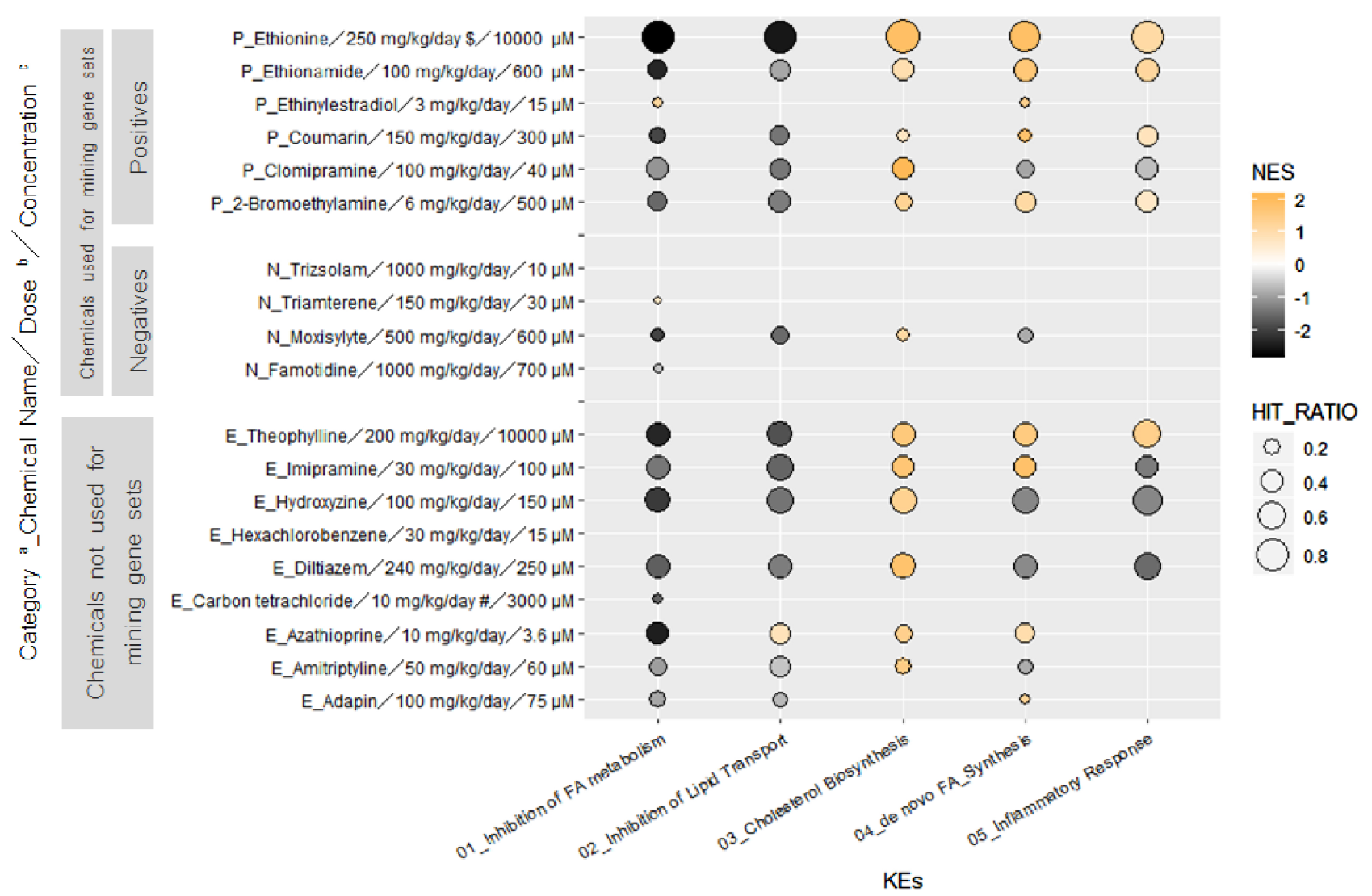

Fig. 1. Results of Gene Set Enrichment Analysis (GSEA) for KEs to Evaluate Fatty Degeneration of Hepatocytes

a“"Category" P: Positive for fatty degeneration of hepatocytes; N: Negative for fatty degeneration of hepatocytes; E: External chemicals. b" Dose": Minimum dose at which fatty degeneration of the hepatocytes was observed in 28-day treatment. "“Concentration": Highest concentration tested in rat primary hepatocytes. $\$$ : Fatty degeneration of the hepatocytes in 28-day treatment was not observed. \#: Minimum dose observed in TGP experiment. (Color figure can be accessed in the online version.) 
tiazem, Hexachlorobenzene (HCB), Hydroxyzine, Imipramine，Theophylline] では，7物質において 肝細胞における蓄積に関連すると考えられる KEs を, rPH の GEx に基づき NES 及び Hit Ratio とし てスコア化できた。なお， $\mathrm{CCl}_{4}$ については，in vivo では CYP2E1，CYP2B1 又は CYP2B2 により 活性代謝物である $\mathrm{CCl}_{3}$ ラジカルが生成すると考え

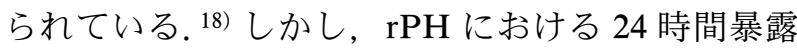
の CYP2E1 及び CYP2B1/CYP2B2 の GEx を確認 したところ，CYP2E1 及び CYP2B1/CYP2B2 はそ れぞれ in vivo の約 $1 / 15$ 及び約 $1 / 12$ 程度であり， 活性代謝物が生成していない可能性が考えられた。 また，HCBについては，Fig. 1 に示すどの物質よ りも対水溶解度が低く $\left(0.0062 \mathrm{mg} / \mathrm{L}^{19)}\right)$ ，十分な 濃度で試験が実施できていない可能性が考えられた。

5. まとめ

ラット肝臓における GEx の解析結果に基づき, GEx で評価可能と考えられる肝細胞脂肪変性に至 るイベントを特定した．また，特定したイベントに ついて rPH の GEx に基づく GSEA による評価が できる遺伝子セットを作成した。その結果, $\mathrm{rPH}$ の GEx に基づき算出されるスコアが in vivo 系で検 出された六進/抑制を反映した結果であったことか ら，これらの指標を肝毒性評価に利用できる可能性 があると考えられた。 今後, GSEA スコア及び Tox21 等で取得されている in vitro 試験デー夕等を 用いた肝毒性予測モデル構築の検討を行う。また, 科学的知見等の蓄積に応じて, 遺伝子セットの見直 しを行うことで, より汎用性が広く, 高精度な肝毒 性予測モデルへ高めていきたい.

謝辞本研究の実施の共同研究者である, 一般 財団法人化学物質評価研究機構の作永真由美氏及び 大野文子氏に深く感謝する。本研究の一部は, 経済 産業省「材料の社会実装を支える高速・高効率な安 全性評価技術の開発一毒性関連ビッグデータを用い た人工知能による次世代型安全性予測手法の開発一 (AI-SHIPS プロジェクト)」の一環で実施したもの である.

利益相反＼cjkstart開示すべき利益相反はない.

\section{REFERENCES}

1) Abe T., Kobayashi K., Nishikawa S., Yamada T., Hasegawa R., Sakuratani Y., Yamada H., Hirose A., Kamata E., Yoshida M., Sunouchi M., Honma M., Yamashita T., Sakai K., Yamazoe Y., Hayashi M., PHARM STAGE, 12, 39-47 (2012).

2) Ankley G., Bennett R., Erickson R., Hoff D., Hornung M., Johnson R., Mount D., Nichols J., Russom C., Schmieder P., Serrrano J., Tietge J., Villeneuve D., Environ. Toxicol. Chem., 29, 730-741 (2010).

3) Organisation for Economic Co-operation and Development. "Adverse Outcome Pathways, Molecular Screening and Toxicogenomics.": 〈https: // www.oecd.org / chemicalsafety / test ing/adverse-outcome-pathways-molecularscreening-and-toxicogenomics.htm $\rangle$, cited 17 July, 2019.

4) European Chemicals Agency, "Guidance on Information Requirements and Chemical Safety Assessment Chapter R.7a: Endpoint specific guidance," Version 6.0, 2017.

5) Brockmeier E., Hodges G., Hutchinson T., et al., Toxicol. Sci., 158, 252-262 (2017).

6) WikiPathways. "Liver Steatosis AOP (Homo sapiens)": 〈https://www.wikipathways.org/ index.php/Pathway:WP4010〉, cited 17 July, 2019.

7) Knapen D., Angrish M., Fortin M., Katsiadaki I., Leonard M., Margiotta-Casaluci L., Munn S., O’Brien J., Pollesch N., Smith L., Zhang X., Villeneuve D., Environ. Toxicol. Chem., 37, 1723-1733 (2018).

8) Landesmann B., Goumenou M., Munn S., Whelan M., JRC Scientific and Policy Reports, JRC75689, 2012.

9) Chemicals Evaluation and Research Institute, Japan. "Activities in Tox-Omics.": 〈http:// www.cerij.or.jp/research_assistant_project / tox_omics.html $\rangle$, cited 17 July, 2019.

10) Uehara T., Ono A., Maruyama T., Kato I., Yamada H., Ohno Y., Urushidani T., Mol. Nutr. Food Res., 54, 218-227 (2010) .

11) Puddu P., Caldarera C., Marchetti M., Biochem. J., 102, 163-167 (1967).

12) Farrell G., van Rooyen D., Gan L., Chitturi 
S., Gut Liver, 6, 149-171 (2012).

13) Thoolen B., Maronpot R., Harada T., Nyska A., Rousseaux C., Nolte T., Malarkey D., Kaufmann W., Küttler K., Deschl U., Nakae D., Gregson R., Vinlove M., Brix A., Singh B., Belpoggi F., Ward J., Toxicol. Pathol., 38, 5S-81S (2010).

14) Mootha V., Lindgren C., Eriksson K., et al., Nat. Genet., 34, 267-273 (2003).

15) Subramanian A., Tamayo P., Mootha V., Mukherjee S., Ebert B., Gillette M., Paulovich A., Pomeroy S., Golub T., Lander E., Mesirov J., Proc. Natl. Acad. Sci. USA, 102, 15545-15550 (2005).
16) Broad Institute, Inc. "Molecular Signatures Database v6.2”: 〈http://software.broadinsti tute.org/gsea/msigdb/index.jsp $\rangle$, cited 17 July, 2019.

17) Broad Institute, Inc. "Gene Set Enrichment Analysis”: 〈http://software.broadinstitute. org/gsea/index.jsp $\rangle$, cited 17 July, 2019.

18) Weber L., Boll M., Stampfl A., Crit. Rev. Toxicol., 33, 105-136 (2003).

19) Farmer W., Yang M., Latery J., "Residual Management by Land Disposal: Proceedings of the Hazardous Waste Research Symposium," 1976, pp. 177-185. 